\title{
A MULHER, O MAL? - REPRESENTAÇÕES DO FEMININO EM JOSÉ SARAMAGO
}

\author{
Débora Renata de Freitas Braga \\ Otávio Rios
}

(Universidade do Estado do Amazonas)

\begin{abstract}
RESUMO
Nesta pesquisa propomos analisar a representação feminina na literatura pela perspectiva masculina, para verificar em que medida o posicionamento do autor se vincula (ou não) aos preceitos e (pre)conceitos da moral cristã - a mulher portadora do pecado original, causa dos infortúnios masculinos, propensa à bruxaria e à sedução como veículo de insubordinação -, e o que os vestígios deste olhar masculino implicam. À luz de teóricos como Gilles Lipovetsky e ensaístas como Helder Macedo, Maria Alzira Seixo, Beatriz Berrini e Maria de Fátima Marinho, elegemos as obras Caim, Memorial do Convento e Ensaio sobre a cegueira, de José Saramago. Partindo do pressuposto de que as personagens possuem elementos comuns entre si, dividimos a pesquisa em dois momentos: no primeiro, discutiremos como se configura o feminino em Saramago sob os aspectos do olhar, do erotismo, da sedução e da magia, para verificar de que maneira são relevantes na configuração de seus papéis no universo masculino; no segundo passo, analisaremos quatro personagens - eva e lilith, de Caim; Blimunda, do Memorial do Convento e a mulher do médico, do Ensaio sobre a ceguei$\mathrm{ra}$, identificando os elementos apontados anteriormente e comparando-os.
\end{abstract}

PALAVRAS-CHAVE: José Saramago; Feminino; Magia.

\section{ABSTRACT}

In this research we propose to analyze the representation of women in literature from the male perspective, to see to what extent the author's position is linked (or not) the rules and (pre) concepts of Christian morality - the woman with original sin, because of misfortunes men, prone to sorcery and seduction as a vehicle for insubordination - and what remains of this male gaze imply. In light of theorists such as Gilles Lipovetsky and essayists as Helder Macedo, Maria Alzira Seixo, Beatriz Berrini and Maria de Fátima Marinho, elected works Caim, Memorial do Convento and Ensaio sobre a cegueira, by José Saramago. Assuming that the characters have elements in common with each other, share research in two stages: the first, we discuss the configuration of the feminine in Saramago under the aspects of the look, eroticism, seduction and magic, to verify that way are relevant in shaping their roles in the male universe, in the second step, we analyze four characters - eva and lilith, for Caim, Blimunda, for Memorial do Convento and mulher do médico, for Ensaio sobre a cegueira, identifying the elements mentioned above and comparing them.

KEYWORDS: José Saramago; Female; Magic. 
As sereias, um canto sedutor, arrastando os marinheiros para o fundo do oceano. Joana D’Arc a queimar no fogo da Inquisição. A Lilith Sixtina, de Dèlacroix: rosto de mulher, corpo de serpente, a tentar Eva no Paraíso. Capitu, que atormenta os pensamentos de Bentinho em Dom Casmurro. Na mitologia, na História, na pintura e na literatura é sempre uma mulher - com poucas exceções - a responsável pelos infortúnios dos homens. Na produção literária portuguesa, objeto de nossa pesquisa, Helder Macedo (2002, pp. 201-214) aponta três representações femininas em sua relação com o mal ou o pecado: três "faces de Eva" nas cantigas medievais líricas e satíricas. Segundo o ensaísta, a senhor das cantigas de amor é inalcançável e egoísta, e ignora o amor do trovador, fazendo-o sofrer: na relação de vassalagem, a mulher figura como ícone, inacessível ao homem. Nas cantigas de amigo, é substituída pela imagem daquela que espera o retorno do amante: um feminino erotizado e lascivo, a lavar, significativamente, os cabelos numa fonte ${ }^{1}$. Por fim, especialmente nas cantigas de escárnio e maldizer, observamos uma representação da mulher diabólica e nefasta: seja na aparência, seja nas atitudes, é ridicularizada pelo eu-lírico, o que, de acordo com Macedo, torna evidente o medo masculino em relação à sexualidade feminina (MACEDO, 2000, p. 210). E assim, neste baile de máscaras, quem as utiliza é a mesma Eva retratada na narrativa genesíaca: mulher ardilosa, inclinada à desobediência, eventualmente ligada ao feio, ao abjeto e ao caótico. Aparentemente, para "que a mulher apareça como uma personalidade autônoma, capaz de assumir sua própria identidade sexual” (MACEDO, 2000, p. 205), seria necessário conferir-lhe um poder destrutivo.

Segundo Delumeau, “o primeiro acontecimento 'monstruoso' da história foi produzido pela diabólica serpente que seduziu Eva” (DELUMEAU, 2006, p. 462), o que culminou na figuração do feminino como agente da desordem e desequilíbrio, qual seja, portador do pecado original. Frequentemente a mulher, quando não é evocada como ser de caráter fraco, compactuante com o logro, a manipulação e a vingança, é apresentada de maneira submissa e angelical. É a partir deste pressuposto que Gilles Lipovetsky (2000) delineia três concepções de feminino, as quais se assemelham às "três faces de Eva" apontadas por Macedo: a "primeira mulher", demonizada e antagonista do homem; a "segunda mulher", enaltecida, apática e objetificada; e a "terceira mulher", sujeita de si. Tanto na primeira quanto na segunda concepções, não exerceriam participação expressiva na sociedade, vivenciando um processo de exclusão que as tornou o "exótico", o "ex-cêntrico", a ser temido, subjugado ou elevado à condição de eterna vítima. A “terceira mulher” concebida por Lipovetsky (2000), invenção da sociedade pós-guerra, surge quando a "identidade feminina deixa de ser o Outro do mesmo para se tornar uma procura e uma invenção" (RECTOR, 1999, p. 46). Se, conforme Monica Rector, "inicialmente, os estudos que proliferaram no âmbito acadêmico baseavam-se em tópicos comuns como a opressão da mulher, para mostrar que o domínio do homem era uma constante" (RECTOR, 1999, p. 45), neste trabalho investigamos o processo 
inverso: nas obras de José Saramago, as personagens masculinas parecem se mover no tecido da narrativa como cegos num labirinto, guiados por um fio invisível - Teseu pelas mãos de Ariadne. Tendo as personagens femininas como fio condutor, é um novo papel da mulher que se constrói na e para uma história bordada literariamente, ou, como afirma Teresa Cerdeira, são mulheres "trazidas [...] para reverterem, na criação, o processo temporal que quereria esmagá-las" (CERDEIRA, 2000, p. 216). Uma vez que, nesta ressignificação do feminino, não há subordinação, e sim justaposição dos gêneros, permitimo-nos pensar que uma nova mulher vive nos romances de Saramago: uma personagem reinventada na outra. Nas narrativas que elencamos para análise, não ocorre luta de sexos, mas uma jornada de autoconhecimento, na qual a mulher é posta em evidência por exercer função de guia no universo masculino, contando com os atributos do olhar, da magia e da sedução.

Mas o que são os olhos de Medusa, senão o símbolo do medo que petrifica? E as Greias, velhas bruxas da mitologia grega, compartilhando um único olho a fim de enunciar o destino de quem ousa lhes perguntar? Na literatura portuguesa também é evidente o fascínio pelos olhos, a lembrarmos dos olhos verdes de Joaninha, protagonista da novela inserida nas Viagens de Almeida Garrett, que fazem "abalar-se pelos fundamentos o [...] catolicismo" (GARRET, 1992, p. 83). Porém, em que medida se torna relevante refletir a respeito de olhos femininos no Portugal pós-25 de abril? Na visão de Horácio Costa (1999), Saramago apresenta um Portugal "cego" pelo fervor da moralidade cristã e pela mutilação intelectual imposta por meio da ditadura, sinalizando, de forma irônica, que em terra de cegos a mulher é a única a ver, de fato. A obsessão pelo olho (corpo físico) desencadeador do medo - a Medusa e as Greias, por exemplo - ou da paixão é desconstruída nos romances saramaguianos, e se torna exacerbação do olhar que (metaforicamente) apreende o mundo.

Tendo o excesso de visão como marca, as personagens absorvem um conhecimento do mundo: olhar que vê, a fundo, a realidade ou a(s) verdade(s) oculta(s). Conforme Marilena Chauí, "a palavra visionário nos vem imediatamente quando pretendemos designar tanto aquele que conhece o futuro quanto aquele que sonha sonhos impossíveis, tanto aquele que vê mais e melhor do que nós quanto aquele que nada vê" (CHAUÍ, 1995, p. 32). Sendo assim, nas mulheres da ficção de Saramago é estreito o laço entre olhar, ver e conhecer, do qual os homens vão tomando parte no curso da narrativa. No entanto, elas não possuem a função de movê-los como marionetes, mas de completar-lhes uma ausência, assegurar-lhes uma consciência crítica e, muitas vezes, moral. Beatriz Berrini alega que "os homens [...] vêem o Outro e o mundo com os olhos da mulher, (e que esta, por sua vez,) terá visões e revelações [...], ouvirá vozes" (BERRINI, 1998, p. 142-143), poder acima da compreensão, que o próprio narrador não se encarrega de explicar. A voz masculina não reina absoluta e não detém todas as explicações para os fatos, sendo assim, as personagens acabam 
por ganhar autonomia no espaço concedido pela ficção. Segundo Afonso Romano de Sant’anna, "é necessário que um outro olhar fora do sistema venha revelar o que estava oculto" (SANT'ANNA, 2006, p. 23), e as mulheres não apenas veem excessivamente, como assumem também a postura de conhecedoras de Deus, dos homens e dos fatos.

De acordo com Georges Bataille, "a respeito do olho, parece impossível pronunciar outra palavra que não seja sedução, pois nada é tão atraente quanto ele no corpo dos animais e dos homens. Porém, a sedução extrema está provavelmente no limite do horror" (BATAILLE, 2003, p. 99). Se o olhar das personagens promove o questionamento do ser e certa sabedoria, é plausível considerá-los como veículo tanto de (cons)ciência quanto de erotismo. O erotismo, consoante o conceito de Bataille (1987), é fundamentalmente um ato transgressor. Quando o interdito é exercido, a atividade erótica perde o seu conteúdo sexual e é impulsionada pelo desejo de conhecer a si e ao outro: é quando o olhar se faz anunciador deste processo de comunhão. Também é por meio do olhar que as personagens seduzem - no sentido primário de "desviar" ou "conduzir" - os homens, guiando-os a uma verdade a qual, até então, permanecera oculta. Por conseguinte, sob o olhar de Maria de Fátima Marinho, "o principal fator de sedução parece estar na capacidade de olhar os outros por dentro e nas consequências que daí podem advir" (MARINHO, 2009, p. 84), dentre as quais citamos a insubordinação ao poder patriarcal e/ ou divino. Aparentemente, sob o olhar de Lipovetsky, depararíamo-nos com o recorrente "imaginário tradicional da sedução feminina confundida com os malefícios de Eva” (LIPOVETSKY, 2000, p. 172). Todavia, como o ato de ver é, sobretudo, uma ousadia (SANT'ANNA, 2006), as Evas de Saramago são, por si só, um enigma, dotadas de capacidades sem explicação, sendo muitas vezes tachadas de bruxas ou hereges. E a audácia de "ver além" pode ser confundida com feitiçaria.

Conforme Monica Figueiredo, no ensaio "Ruínas, vestígios e silêncios: Lilias Fraser, de Hélia Correia” (2009), a ficção de Hélia Correia afirma a mulher como o diferente, atribuindo-lhe o estatuto da marginalidade ou da loucura. Lilias Fraser, protagonista que dá título ao romance, transita entre a errância e a insulação, amedrontada pelo dom de prognosticar o futuro. Seus olhos amarelos instigam e perturbam, porém, segundo a ensaísta, a dádiva de prever os acontecimentos vindouros se torna uma maldição, e é inútil, visto que Lilias não pode interferir no rumo dos acontecimentos. As sucessivas tragédias que prevê a silenciam, tornando-a espectadora da barbárie. Talvez possamos estabelecer paralelos entre as escritas de Hélia Correia e Saramago, contudo, aquela concebe "personagens femininas que desestabilizam, a seu modo, a ordem aceita em nome de propósitos envoltos em mistério e magia" (FIGUEREDO, 2009, p. 152), enquanto na narrativa saramaguiana não há, propriamente, relação entre o feminino e o ato de bruxaria ou paganismo: não há maniqueísmo nem ingenuidade, e as mulheres se fazem conhecedoras de seu lugar junto ao homem. Sujas, os seios nus, completamente despidas ou com as roupas rasga- 
das, amam, matam, quebram tabus e se sacrificam. Humanas, sem dúvida, e paradoxalmente mantêm íntima relação com o sagrado que está aquém (e talvez além) do sentido religioso. Portanto, uma vez que o conhecimento e o erotismo oriundos da visão excessiva exprimem a percepção do divino ${ }^{2}$,

as mulheres em rebelião não estariam tentando erguer esse teto-tampa? Judite, a heroína bíblica, não realizou o mesmo ato de decapitação da personagem de seu último romance? As heroínas guerreiras não são constrangidas a essa sublevação do "teto" sagrado do mundo? (CLEMÉNT \& KRISTEVA, 2001, p. 41)

No Malleus Malleficarum (KRAMER \& SPRENGER, 2004) há o pressuposto de que a mulher possui menos fé (do latim feminus: fe + minus) do que o homem. Eva, portanto, saída da costela de Adão, seria torta moralmente. No entanto, Catherine Clément e Julia Kristeva (2001) utilizam o termo "olhar visionário", que seria inerente à mulher: olhar constituído como experiência tanto sagrada quanto profana, ao mesmo tempo em que o feminino se identifica com o sagrado e se rebela contra ele. Clément \& Kristeva afirmam que, mesmo resistente, o feminino está ligado ao sagrado porque é o responsável por promover a ligação entre a "vida" e o "sentido". Ao contrário de Lilias Fraser, que opta pelo "calar", as mulheres tecidas por Saramago decidem pelo "intervir", atuando de forma ativa na trajetória dos homens. Uma de suas características marcantes, a abnegação, também garante sentido à existência: da maldição à opressão, a mulher caminhou rumo à autoafirmação. Ainda de acordo com Clément \& Kristeva, o sagrado também pode estar ligado ao feminino pelo abjeto. Por meio do corpo em estado impuro, a mulher alcança uma "iluminação confusamente semelhante a Deus" (CLÉMENT \& KRISTEVA, 2001, p. 41): a consciência de estar no mundo e entendê-lo. Mas, na ficção saramaguiana, as mulheres não têm escolha, porque nelas o sujo "ora exalta, ora castiga" (CLÉMENT \& KRISTEVA, p. 44). E se o excesso de visão é fundamental para o conhecimento, também acarreta uma carga de responsabilidade nem sempre agradável. Bênção ou maldição, os olhos femininos testemunham a barbárie e vivenciam o horror como ninguém, e é do testemunho feminino que se recupera a memória, a qual ficara perdida para sempre no discurso monumental. Assim, Saramago acaba por subverter a recorrente temática da submissão sem cair no equívoco de afirmar a igualdade dos sexos, porém, mantendo o discurso de reificação feminina, em que uma personagem se completa na outra. A "terceira mulher", ou outra "face de Eva" na literatura portuguesa, é esboçada nas linhas do texto; logo, um novo rumo é traçado para o feminino. Fragmentado em personagens de tempos, espaços, aparências e narrativas variadas, como boneca russa, as personas se encaixam. São mulheres de tinta, "levantadas do chão": Herdeiras de Eva.

De acordo com a Torá judaica, a primeira mulher criada por Deus foi Lilith. Por ter questionado o Criador a respeito da posição submissa que lhe fora imposta, a companheira de Adão, na versão mais conhecida do 
mito, foi expulsa do Éden e condenada a vagar pelo mundo, insuflando os homens contra Deus, o que a tornou o primeiro demônio. A ousadia teve seu preço, mas a obscura personagem se encheu de ódio ao descobrir que Deus fabricara uma nova mulher, e resolveu persuadi-la a comer o fruto da árvore do conhecimento. O resto da história já sabemos: Eva, a segunda esposa de Adão, teve sua imagem associada ao pecado, recaindo sobre si a culpa pela Queda do Homem. Há um quadro no Museu de Grenoble, na França, que se chama A expulsão de Adão e Eva do Paraíso. A obra de 1633, pintada por Domenico Zampieri, retrata Adão a apontar a esposa como culpada, tentando esquivar-se do julgamento de Deus e do olhar acusador de seus anjos. Eva, por sua vez, está deitada na relva, a sorrir, complacente, para o Senhor. Eva é vista, equivocadamente, como a mulher submissa que corrompe o homem, e Lilith, como a primeira a lutar pelos direitos iguais. O mito de Lilith foi banido das escrituras cristãs, mas em Eva permaneceu o estereótipo do feminino transgressor, a mola propulsora do pecado original, como verificamos na pintura de Zampieri. Conforme diz Lipovetsky, "como não se interrogar sobre o novo lugar das mulheres em sua relação com os homens quando nosso meio século mudou mais a condição feminina do que todos os milênios anteriores?” (LIPOVETSKY, 2000, p. 11). Deste modo, no contexto de produção das três obras de Saramago elencadas para análise, faz-se necessário discutir o que há em comum nesta personagem múltipla, pois aparentemente é aglutinada sob um único conceito: o da invariância, instaurando a "contraposição entre a ordem masculina enceguecedora e a feminina reveladora” (SANT’ANNA, 2006, p. 147).

Em Caim (2009), eva e lilith ${ }^{3}$ assumem o protagonismo. Ao subverter o mito judaico de Lilith e parodiar a criação de Adão e Eva, o autor arquiteta uma mulher duplicada, o duplo alicerce da viagem de adão e caim, talvez da própria narrativa. Da criação do mundo ao dilúvio, “a instrutiva e definitiva história de caim a que, com nunca visto atrevimento, metemos ombros" (SARAMAGO, 2009, p. 13) é outra reconstrução paródica da Bíblia, mais especificamente do relato genesíaco ${ }^{4}$, pontuado pela ironia cortante do narrador e pelos feitos dos cinco personagens centrais: deus, adão, eva, caim e lilith. Caim, o primeiro assassino, viaja no tempo e no espaço $0^{5}$ para confrontar deus, a quem considera o verdadeiro culpado pela morte do irmão abel. As sucessivas viagens revelam a caim (e ao leitor) um deus vingativo e manipulador. Todavia, como é recorrente na ficção saramaguiana, é a mulher quem assume a responsabilidade de retirar a venda de ignorância do homem, inaugurando o conflito no romance. E eis que surge eva, a heroína primeira de Saramago ${ }^{6}$.

Segundo Lipovetsky, o que caracteriza a "terceira mulher", como explanamos na primeira parte deste trabalho, é a "autonomização em relação à influência tradicional exercida pelos homens sobre as definições e significações imaginário-sociais da mulher" (LIPOVETSKY, 2000, p. 236). Em Caim, o autor mantém a ideia de que eva incita adão a provar do fruto, no entanto, a metáfora é reconfigurada de modo a pensarmos que a mulher 
possibilita a obtenção do conhecimento. Adão degusta, mas, ironicamente, um pedaço fica preso na garganta - o pomo de adão - e o saber torna-se uma faculdade intrínseca ao feminino, "o laço entre ver e conhecer, de um olhar que se tornou cognoscente e não apenas espectador desatento" (CHAUÍ, 1995, p. 35). Eva, desde o momento em que deus lhe enfiou "a língua pela garganta abaixo" (SARAMAGO, 2009, p. 9), tornou a linguagem sua arma de questionamento e crítica. Em relação a ela, entendemos como olhar diferenciado o sonho revelador com a serpente, capacidade que escapa aos domínios do próprio deus. O olhar de eva está diretamente ligado à sua percepção das coisas e do mundo, à consciência de si como mulher e como esposa, insatisfeita com a subordinação ao marido. É o que verificamos nesta passagem, onde se percebe a astúcia feminina em ação:

Revolveu-se o senhor contra a mulher e perguntou, Que fizeste tu, desgraçada, e ela respondeu, A serpente enganou-me e eu comi, Falsa, mentirosa, não há serpentes no paraíso, Senhor, eu não disse que haja serpentes no paraíso, mas digo sim que tive um sonho em que me apareceu uma serpente, e ela disse-me, Com que então o senhor proibiu-vos de comerem do fruto de todas as árvores do jardim, e eu respondi que não era verdade, que só não podíamos comer do fruto da árvore que está no meio do paraíso e que morreríamos se tocássemos nele, As serpentes não falam, quando muito silvam, disse o Senhor, A do meu sonho falou. (SARAMAGO, 2009, p. 17)

Eva é entendida, portanto, como a primeira visionária da História. É a consciência ausente de adão, que revela por meio do sonho as intenções ocultas de deus ao negar o acesso ao conhecimento. Tendo o sonho como artifício (ou não), eva aprende a utilizar a dialética a seu favor, chegando ao ponto de discutir com o próprio criador a respeito da proibição estabelecida por este. Lembremos que a personagem estava a par de que possuía os olhos fechados. Nas suas palavras: "abriríamos os olhos e ficaríamos a conhecer o mal e o bem como tu os conheces, senhor" (SARAMAGO, 2009, p. 17).

Há um momento em que eva sugere interrogar deus e "o forçar a explicar-se, e a primeira coisa que deverá dizer-nos é a razão por que nos fez e com que fim" (SARAMAGO, 2009, p. 22). Sendo assim, a sua sede de conhecimento traduz-se como atividade erótica de descoberta de si e do outro. Recordemos que, na Bíblia, é utilizado o termo "conhecer" como sinônimo de manter relações sexuais com alguém ${ }^{7}$, mas em Caim, somente após deus colocar a língua à força na boca do primeiro casal, "pela primeira vez, adão disse para eva, Vamos para a cama” (SARAMAGO,2009, p. 11). Na narrativa ocorre, portanto, uma conexão entre erotismo e linguagem. Entretanto, deus surge como o interdito ao erotismo, e eva, com seu sonho enigmático - ou visão excessiva -, desobedece a ordem divina. $\mathrm{O}$ ato transgressor da personagem proporciona a adão uma experiência significativa: a expulsão, a qual possibilitou o entendimento da vida como uma trajetória 
árdua de trabalho, abarrotada de injustiça e sofrimento, o que provavelmente não testemunhariam se permanecessem no Paraíso alienante concebido por deus.

Em sua relação com adão, eva permanece subordinada, mas no momento em que planeja convencer o querubim que guarda o Paraíso, azael, a ceder-lhe algum alimento, aparentemente esquece o papel submisso que fora obrigada a exercer e assume a responsabilidade. Eva questiona as afirmações de adão, o que a deixa "surpreendida consigo mesma, com a liberdade com que tinha respondido ao marido, sem temor, sem ter de escolher as palavras, dizendo simplesmente o que, em sua opinião, o caso justificava" (SARAMAGO, 2009, p. 23). Com os seios balançando ao ritmo da caminhada, se sente feliz por ter agido com liberdade, até que cria consciência de si como mulher e das limitações que possui:

Eva caminha mais lentamente que antes, e não é porque se sinta cansada. Adão, se aqui estivesse, de certeza se riria dela, Tão valente, tão valente, e afinal vais aí cheia de medo. Sim, tinha medo, medo de falhar, medo de não ter palavras suficientes para convencer o guarda, chegou mesmo a dizer em voz baixa, tal era o seu desânimo, Se eu fosse homem seria mais fácil. (SARAMAGO, 2009, pp. 23-24)

As seduções promovidas por eva podem ser entendidas de três maneiras: no sentido de desvio, condução ou atração. Há desvio quando a personagem oferece ao homem o fruto proibido, ou seja, convida-o a partilhar do saber que lhe fora vedado. Mas também há condução porque, ao fazer com que deus os expulse do Éden, eva sujeita adão a conviver com as dificuldades do mundo real, longe da ignorância passiva vivida no Paraíso. Por fim, a sedução é bem sucedida no momento em que azael cede aos seus encantos: a famosa feminilidade que atrai e corrompe até mesmo um anjo de deus.

Apesar da sujeira impregnada na pele, debilitada pelas sucessivas "diarreias", eva desnuda-se diante do querubim e lança um sorriso em troca do sustento de si e do companheiro. A personagem compreende que a aparência execrável não a impede de atrair o que deseja, utilizando seus artifícios femininos: "o seu corpo estava coberto de sujidade, as unhas negras como se as tivesse usado para cavar a terra, o cabelo como um ninho de enguias entrelaçadas, mas era uma mulher, a única" (SARAMAGO, 2009, p. 25). O sonho, a expulsão do Éden, a vida em meio à sujeira, à fome e a barganha empreendida com o anjo possibilitaram uma nova leitura da eva ficcional: mulher que conquistou o acesso ao livre pensamento e uma nova atitude diante de deus e do homem: "era como se dentro de si habitasse uma outra mulher, com nula dependência do senhor ou de um esposo por ele designado, uma fêmea que decidira, finalmente, fazer uso total da língua e da linguagem" (SARAMAGO, 2009, p. 23). A vida pós-Éden nunca mais seria a mesma, e a trajetória de libertação, conhecimento e trabalho das personagens permite-nos fitar a poeira que restou por baixo do tapete 
e, a partir dela, constituir para eva um novo lugar, uma nova história. Foi a primeira mulher que ousou desafiar as ordens de deus e do marido, porém, nos primeiros capítulos, após cumprir a sua "função" na história, a "imaginosa" (SARAMAGO, 2009, p. 38) mãe de caim desaparece e cede lugar à lilith, a amante.

Lilith está bem distante do ideal de mulher casta e obediente. As atitudes paradoxais da personagem agridem a sociedade, pois atua de forma dominadora em seus casos extraconjugais e, ao mesmo tempo, procura agir de acordo com as aparências, conforme o que lhe é conveniente. Devora e toma para si o que deseja, sem se incomodar com julgamentos alheios: "não é escravo aquele que se deita em minha cama, ou talvez o seja, mas de mim e do meu corpo" (SARAMAGO, 2009, p. 70). Como não está disposta a se anular em função dos homens que possui, é caracterizada como feiticeira pelos habitantes da terra de nod, da qual é a senhora:

Quem é, perguntou caim, É lilith, a dona do palácio e da cidade, oxalá não ponha os olhos em ti, oxalá, Porquê, Contam-se coisas, Que coisas, Diz-se que é bruxa, capaz de endoidecer um homem com os seus feitiços, Que feitiços, perguntou caim, Não sei nem quero saber, não sou curioso, a mim basta-me ter visto por aí dois ou três homens que tiveram comércio carnal com ela, E quê, Uns infelizes que davam lástima, espectros, sombras do que haviam sido. (SARAMAGO, 2009, p. 51)

Porém, não é só a beleza da personagem que seduz e atormenta, mas também a maestria de tornar-se desejada sem se converter em objeto, como quando "ajuntou as pregas do vestido fazendo escorregar lentamente as mãos pelo corpo [...], primeiro os seios, logo o ventre, depois o princípio das coxas onde se demorou, e tudo isto o fez enquanto olhava o homem fixamente, sem expressão, como uma estátua" (SARAMAGO, 2009, p. 57). Dotada de uma beleza extraordinária, pela qual o tempo aparentemente não passa, lilith é o protótipo da mulher que atrai e enfeitiça os homens, tornando-os meros fantasmas. A figura esfíngica a insinuar-se para o amante denota que "a mulher continua a ser inapreensível, enigma cuja sedução permanece inalterável” (LIPOVETSKY, 2000, p. 67).

Surpreende ao leitor a fidelidade que lilith garante a caim, principalmente quando esta assume uma atitude passiva, não exercida sequer com o marido, noah. Caim é o exilado, usurpador da identidade alheia, marcado por deus com uma mancha negra na testa. Lilith, por sua vez, é quem "lhe dará destino" (SARAMAGO, 2009, p. 55): mulher cuja fama não teme e cujo nome repete com orgulho e como afirmação de sua autoridade. A atitude imperativa de lilith é mantida, principalmente, no momento do ato sexual:

Veja-se esta mulher que, não obstante estar enferma de desejo, como é fácil perceber, se compraz em ir adiando o momento da entrega, palavra por outro lado altamente 
inadequada, porque lilith, quando finalmente abrir as pernas para se deixar penetrar, não estará a entregar-se, mas sim a tratar de devorar o homem a quem disse, Entra. (SARAMAGO, 2009, p. 59)

No Malleus Malleficarum (2004), insinua-se que a lascívia é intrínseca à natureza feminina. O sexo, que durante muito tempo fora considerado um ato indigno e abjeto, é ressignificado no romance como a forma mais íntima de união do casal, a exemplificarmos com o trecho em que caim revela não ser abel o seu verdadeiro nome, e lilith responde: "vamos para a cama, arderei aqui mesmo de desejo se não me acodes, foste o Abel que conheci entre os meus lençóis, agora és o caim que me falta conhecer" (SARAMAGO, 2009, p. 67). Na obra, o erotismo ultrapassa a fronteira do sexo e se revela como forma de conhecimento do parceiro. A conexão física aparenta ser tão intensa, que lilith pressente o retorno de caim à terra de nod. Mulher cuja capacidade de entendimento da vida e seus mistérios extrapola o vulgar, lilith abriga em si vestígios de eva (ou vice-versa), pois a mesma tendência aos sonhos premonitórios e ao questionamento da autoridade se notam presentes, configurando-a também como visionária e transgressora:

Como soubeste que vinha hoje, se eu próprio me encontrei nestes sítios sem dar por isso, Nunca me perguntes como sei o que digo que sei porque não poderia responder-te, esta manhã, quando acordei, disse em voz alta, Voltará hoje, disse-o para que tu ouvisses, e foi verdade, aqui estás. (SARAMAGO, 2009, p. 125)

A insubordinação ao marido também é um traço marcante na personagem. Quando noah se revolta com a ausência de respeito por parte de lilith, esta responde: "poderias ser um amante de primeira classe, poderias ter-me feito não um filho, mas dez, e, ainda assim, não te respeitaria” (SARAMAGO, 2009, p. 68). Na aparência, ela finge seguir as convenções sociais, e na vida íntima, governa a cidade, o palácio e seus homens. Todavia, lilith possui outra função na narrativa, que é despertar em caim o desejo de confrontar deus. Ao dizer: "vejo em ti um homem a quem o senhor ofendeu" (SARAMAGO, 2009, p. 67), podemos inferir que os olhos de lilith enxergam através da superfície de caim, e da mácula de assassino evidenciada em sua testa. É ela quem o faz contar-lhe a própria história, assumir o verdadeiro nome, e o conduz da andança sem rumo a uma viagem de descobertas. A partir de então, caim percebe que deve seguir adiante em busca das respostas que almeja, e lilith consente em sua partida, ainda que sua presença lhe venha a ser negada para sempre.

Há outra personagem que, apesar da participação mínima, merece destaque: a mulher de job, cuja inserção na narrativa revela que o autor optou por mostrar o outro lado da história. Após testemunhar a morte dos dez filhos, perder todos os seus bens e ter de conviver com o marido castigado pela lepra, a mulher de job revela-se a consciência lúcida da qual este 
não mais dispõe, especialmente quando alega que "se estivesse no teu lugar, amaldiçoaria a deus ainda que daí me viesse a morte" (SARAMAGO, 2009, p. 139). Novamente, Saramago apresenta-nos uma personagem inclinada a violar regras e instituir o seu próprio código de ética. Da mulher de job também depreendemos uma clareza de raciocínio que pode nos revelar a postura dominante do autor: "o mais certo é que satã não seja mais que um instrumento do senhor, o encarregado de levar a cabo os trabalhos sujos que deus não pode assinar com seu nome" (SARAMAGO, 2009, p. 140). Hereges ou bruxas, o fato é que as personagens rejeitaram o assujeitamento às imposições masculinas (e divinas). Segundo Maria de Fátima Marinho, "reivindicando um estatuto de excepção, essas mulheres transformam a sua precária posição social numa de poder, escondido, mas não menos operante" (MARINHO, 2009, p. 83). Intermediária entre deus e caim, lilith é a responsável por atribuir sentido para o exílio deste último e, consequentemente, para a sua vida, mas tanto lilith quanto a mulher de job insuflam seus homens a abrir os olhos e afrontar deus. Quando lilith declara: "ninguém é uma só pessoa [...], eu sou todas as mulheres, todos os nomes delas são meus" (SARAMAGO, 2009, p. 126), notamos uma multiplicidade do elemento feminino que norteia as obras de Saramago. Prossigamos, pois, a viagem, e ancoremos em Portugal à procura de Blimunda.

Memorial do Convento se constitui em duas narrativas: o papel do rei D. João V e da rainha D. Maria Ana na edificação do Convento de Mafra, e a história de Baltasar e Blimunda, aliada à construção da passarola. $\mathrm{O}$ autor utiliza-se do artifício paródico para contar o processo de construção do Convento, fruto de uma promessa, ao passo que evidencia o caráter sublime da passarola, projeto de sonho e vontades. É neste contexto que emerge a figura de Blimunda Sete-Luas, mulher cuja visão excessiva torna possível a realização do ousado projeto. Blimunda transcende a capacidade de olhar das personagens analisadas anteriormente, porque não somente sonha e prevê os acontecimentos, mas vê, na acepção plena do termo. Nas suas palavras:

Vejo o que está dentro dos corpos, e às vezes o que está no interior da terra, vejo o que está por baixo da pele, e às vezes mesmo por baixo das roupas, mas só vejo quando estou em jejum, perco o dom quando muda o quarto da lua, mas volta logo a seguir, quem me dera que não o tivesse. (SARAMAGO, 1995a, p. 78)

Maria de Fátima Marinho afirma que "a visão transcendente favorece a apreensão de realidades extra-sensoriais, perigosas e desestruturantes de um mundo de aparência" (MARINHO, 2009, p. 85). Em Memorial do Convento, adianta-se a diferença entre olhar e ver que será anunciada no Ensaio sobre a cegueira, e Blimunda é o exemplo da mulher que possui o dom de ver, "não o de olhar, que esse pouco é o que fazem os que, olhos tendo, são outra qualidade de cegos" (SARAMAGO, 1995a, p. 79). Mas o olhar é, para Blimunda, um martírio, pois sabe que nem todos estão prepa- 
rados para assistir à violenta realidade. A lembrarmos que, na simbologia cristã, o pão é a metáfora do corpo de Cristo, e comê-lo significa lembrar-se de seu sacrifício, inversamente, no Memorial do Convento, Vanessa Ribeiro Teixeira aponta que o pão não está ligado a "uma possível elevação espiritual. $\mathrm{O}$ pão levado à boca de Blimunda todas as manhãs, prende-a à vida comum, permitindo que ela viva no mundo dos homens da forma mais prosaica, resguardada pela paisagem visível aos olhos de todos" (TEIXEIRA, 2009, p. 175): uma tentativa de anular, ainda que momentaneamente, a visão que lhe é insuportável.

A mãe de Blimunda, Sebastiana Maria de Jesus, possui o dom da premonição e ouve vozes, mas tende a igualar-se a Deus, como notamos no fragmento abaixo, o único em que Sebastiana assume a voz na narrativa:

Sei que posso ser santa como os santos o são, ou ainda melhor, pois não alcanço diferença entre mim e eles, mas repreenderam-me de que isso é presunção insuportável e orgulho monstruoso, desafio a Deus, aqui vou blasfema, herética, temerária, amordaçada para que não me ouçam as temeridades, as heresias e as blasfémias, condenada a ser açoitada em público e a oito anos de degredo no reino de Angola. (SARAMAGO, 1995a, p. 30)

Ao ser inquirida por Baltasar acerca de seu dom de olhar as pessoas por dentro, Blimunda responde: "o meu dom não é heresia, nem é feitiçaria, os meus olhos são naturais, [...] eu só vejo o que está no mundo, não vejo o que é de fora dele, céu ou inferno, não digo rezas, não faço passes de mãos, só vejo" (SARAMAGO, 1995a, p. 46). Os olhos de Blimunda, ao mudar de cor constantemente, assombram e perturbam, e suas ações denotam um conhecimento oculto que bem poderia ser associado à feitiçaria, como no momento da primeira relação com Baltasar:

Blimunda era virgem. Que idade tens, perguntou Baltasar, e Blimunda respondeu, Dezanove anos, mas já então se tornara muito mais velha. Correu algum sangue sobre a esteira. Com as pontas dos dedos médio e indicador humedecidos nele, Blimunda persignou-se e fez uma cruz no peito de Baltasar, sobre o coração. Estavam ambos nus. (SARAMAGO, 1995a, p. 34)

Sete-Luas driblou a perseguição inquisitorial que poderia sofrer. Seu comportamento desafia o Tribunal do Santo Ofício que, a esta época, permanece em pleno vigor. Em dado momento, afirma que só se confessaria ao padre quando se sentisse pecadora, e acaba por desconcertar um costume católico, cujo fervor marcou a tradição moral e cultural portuguesa. Contudo, Blimunda, ao contrário do que se poderia esperar, não assume uma postura antirreligiosa, mas busca recondicionar a mulher como a verdadeira responsável pela redenção dos homens": "afinal, que faltas são essas nossas, as tuas, as minhas, se nós somos, mulheres, verdadeiramente, o cordeiro que tirará o pecado do mundo" (SARAMAGO, 1995a, p. 242). Os 
questionamentos que Blimunda suscita intentam afirmar a mulher em sua relação com o sagrado. Talvez por este motivo, as vontades das mulheres, as quais Blimunda tem a função de retirar, sejam mais resistentes que as dos homens. A insubordinação à ordem vigente é anunciadora deste processo de autoafirmação feminina, mas há outras personagens que, em maior ou menor grau, desejam livrar-se de algumas determinações da sociedade.

Como é corrente na ficção saramaguiana, a mulher é quem vê, e ao homem resta, por meio de seus olhos, descortinar uma nova realidade. Georges Bataille afirma que "ao amante parece que só o ser amado -, [...] acrescentando a possibilidade da união sensual à união dos corações - pode neste mundo realizar o que nossos limites não permitem, a plena fusão de dois seres, a continuidade de dois seres descontínuos" (BATAILLE, 1987, p. 19). Nos lampejos de paixão, as vontades do casal tornam-se uma só, os "dares e tomares da carne (que propiciaram a Baltasar) um luzeiro espiritual de dupla visão" (SARAMAGO, 1995a, p. 120). O erotismo ultrapassa o sentido carnal e alcança um valor espiritual de comunhão, especialmente quando Blimunda compartilha a refeição com Baltasar, "fazendo seu o que era teu, agora tornando a ser teu o que foi dele, e tantas vezes que se perca o sentido do teu e do meu" (SARAMAGO, 1995a, p. 32-33), antecipando o momento da entrega.

Blimunda "marca uma inegável ruptura histórica" (LIPOVETSKY, 2000, p. 238): com a visão excessiva, tornou possível que Baltasar considerasse a ausência da mão esquerda não como suplício, mas como providência. O padre Bartolomeu Lourenço foi o mentor intelectual da passarola; Baltasar, a força masculina; Blimunda, o olhar norteador, a corrigir as falhas, apontar as mudanças e recolher as vontades, substâncias que fizeram a máquina levantar voo. Entretanto, no primeiro percurso, a passarola arrasta Baltasar para longe, e Blimunda reflete "de que lhe serviu ser capaz de ver o que os outros não vêem, de que lhe serviu ser recolhedora de vontades, se justamente elas foram que o levaram" (SARAMAGO, 1995a, p. 234). Durante nove anos, Sete-Luas percorreu Portugal de ponta a ponta, e assim

conheceu todos os caminhos do pó e da lama, a branda areia, a pedra aguda, tantas vezes a geada rangente e assassina, dois nevões de que só saiu viva porque ainda não queria morrer. Tisnou-se de sol como um ramo de árvore retirado do lume antes de lhe chegar a hora das cinzas, arregoou-se como um fruto estalado, foi espantalho no meio de searas, aparição entre as moradores das vilas, susto nos pequenos lugares e nos casais perdidos. (SARAMAGO, 1995a, p. 241)

Nos seus pés e nos seus olhos se inscreve uma trajetória de busca e peregrinação. Blimunda diz "Vem" (SARAMAGO, 1995a, p. 244), então aceitemos o convite e aprendamos com ela que a realidade não é o que aparenta, e deixemo-nos guiar pela mulher sem nome surgida nas páginas de um Ensaio sobre a cegueira. 
Como em A Metamorfose, de Kafka, quando Gregor acorda e se percebe transformado em um inseto, as personagens do Ensaio sobre a cegueira são acometidas por um mal sem explicação. Paradoxalmente, é a cegueira que torna possível a criação de uma nova visão de si e dos demais, e nesta atmosfera de desespero e descoberta, emerge a figura da mulher do médico. Identificada somente pela posição de esposa do oftalmologista o qual, inicialmente, consideraríamos o protagonista da obra -, a mulher assume o posto fundamental por ser a única a manter a visão intacta, num mundo infestado pela epidemia da "cegueira branca". Não se sabe o motivo pelo qual a mulher do médico permanece com o sentido incólume, e tal capacidade a torna a figura central pelo aprendizado decorrente de sua trajetória como líder do bando de cegos, no manicômio e fora dele, como verificamos a seguir:

Se não formos capazes de viver inteiramente como pessoas, ao menos façamos tudo para não viver inteiramente como animais, tantas vezes o repetiu, que o resto da camarata acabou por transformar em máxima, em sentença, em doutrina, em regra de vida, aquelas palavras, no fundo simples e elementares. (SARAMAGO, 1995b, p. 119)

A mulher do médico proporciona ao leitor um possível esclarecimento sobre a causa da cegueira branca, como podemos observar, ao passo em que, dialogando com o marido, pergunta o motivo pelo qual os homens cegaram, e ela mesma se encarrega de responder: "Queres que te diga o que penso, Diz, Penso que não cegámos, penso que estamos cegos, Cegos que vêem, Cegos que, vendo, não vêem" (SARAMAGO, 1995b, p. 310). Ao criar a noção de que o mundo todo está dentro do manicômio (SARAMAGO, 1995b, p. 102), a mulher do médico cria consciência da barbárie a qual é obrigada a presenciar com seus olhos excessivos, como "uma Blimunda transformada que deixou de ver o interior dos corpos, no seu estado de jejum, para ver agora, de forma também única, o exterior em que eles estão desta vez cegamente imersos e lhes fornecer o seu pão” (SEIXO, 1999, p. 101).

O ponto decisivo do percurso de autoconhecimento da mulher do médico se acentua quando, após matar o líder dos "cegos malvados", descobre que possui coragem suficiente para garantir a sua sobrevivência e a do grupo, ainda que se requisite o uso da violência:

As lágrimas continuavam a correr, mas lentas, serenas, como diante de um irremediável. Levantou-se a custo. Tinha sangue nas mãos e na roupa, e subitamente o corpo exausto avisou-a de que estava velha, Velha e assassina, pensou, mas sabia que se fosse necessário tornaria a matar, E quando é que é necessário matar, perguntou-se a si mesma enquanto ia andando na direcção do átrio, e a si mesma respondeu, Quando já está morto o que ainda é vivo. (SARAMAGO, 1995b, p. 189) 
No início do confinamento, a mulher do médico reflete, como Blimunda: "de que me serve ver. Servira-lhe para saber do horror mais do que poderia imaginar alguma vez, servira-lhe para ter desejado estar cega, nada senão isso" (SARAMAGO, 1995b, p. 152). Do posto de dona-de-casa, a mulher do médico passa à condição de líder de resistência, avessa a qualquer forma de opressão. No entanto, ao contrário do provérbio que diz: "em terra de cegos quem tem um olho é rei", a mulher do médico não é privilegiada na narrativa de José Saramago, pois sua visão descortina um mundo apocalíptico e desumanizado. Em meio ao caos, constrói para si um novo lugar, e "o mistério do feminino, sua dimensão eterna de incerteza e de imprevisibilidade se recompõe, então, mesmo através da abertura e da multiplicação de seus papeis" (LIPOVETSKY, 2000, p. 67).

No Ensaio saramaguiano, o espaço da mulher torna possível a recuperação do sentido da existência e da solidariedade para com o outro. Ao revelar que matara o chefe do bando dos cegos bandidos, a rapariga dos óculos escuros e a mulher do primeiro cego compreendem que o ato fora necessário para libertar a todos da opressão:

Mataste para vingar-nos, para vingar as mulheres tinha de ser uma mulher, disse a rapariga dos óculos escuros, e a vingança, sendo justa, é coisa humana, se a vítima não tiver um direito sobre o carrasco, então não haverá justiça, Nem humanidade, acrescentou a mulher do primeiro cego (SARAMAGO, 1995b, p. 245).

O erotismo na cena do banho da mulher do médico, da rapariga dos óculos escuros e da mulher do primeiro cego, por exemplo, está expresso por meio da "epifania da beleza feminina ligada à epifania da criação verbal, [...] representando o ponto culminante da recuperação da dignidade neste texto quase inteiramente consagrado às formas várias e mais terríveis da abjecção" (SEIXO, 1999, p. 120). A imundície em que a mulher do médico é forçada a viver, o testemunho da barbárie e da desumanização tornam seu corpo um texto no qual se inscreve a história de mulheres destinadas a orientar homens. A compaixão e sabedoria femininas, articuladas com auxílio da visão excessiva, permitem a construção de uma consciência mais humanitária, em contraposição à animalidade de um mundo cego que, em relação ao outro, ainda não vê, tampouco repara.

\section{ÚLTIMAS PALAVRAS}

Ao problematizar a História, a ficção de José Saramago reelaborou ecos tanto do passado - reescrevendo-o e inserindo os marginalizados pelo discurso oficial - quanto do presente, lançando, também, as bases de um futuro idealizado. Como quem se presta a narrar uma outra história, o narrador saramaguiano recondiciona o lugar periférico da mulher, pondo em xeque o patriarcalismo o qual o regime ditatorial reforçou, e a torna 
símbolo de uma revolução que se estendeu para as malhas do texto. Sendo assim, a emergência do sujeito feminino no romance de Saramago revela os pilares de uma narrativa que se projeta, sobretudo, para o futuro.

O caráter onírico e bussolar das personagens saramaguianas evidencia um projeto do feminino libertador, concebido por intermédio de um olhar masculino que mantém as estruturas do discurso reificador sobre a mulher. Da eva ficcional até a mulher do médico, em insuspeita contemporaneidade, verificamos histórias de homens auxiliados por mulheres em uma viagem existencial que os fez ver a si e ao mundo com outros olhos, pois esta sensibilidade do olhar feminino resulta não só na experiência sensorial, mas no desvendamento de si e do outro. Por conseguinte, as mulheres em Saramago "subvertem o código e a rigidez social através do amor, seja ele a paixão física ou o amor de uma ilusão" (MARINHO, 2009, p. 75). Enfim, o escritor ressignifica a mulher a partir de seu lugar junto ao homem, porém, os homens se servem de seus olhos para cumprir a jornada existencial que lhes cabe. Assumindo que possuem sede de conhecimento, violam regras e conduzem o universo masculino, observa-se um feminino múltiplo agrupado sob o mesmo conceito: o legado da mãe genesíaca, uma lição concedida por meio do olhar.

\section{REFERÊNCIAS BIBLIOGRÁFICAS}

BATAILLE, Georges. O Erotismo. Trad. Antônio Carlos Viana. Porto Alegre: L\&PM Editores, 1987.

História do olho. Trad. Eliane Robert Moraes. São Paulo: Cosac Naify, 2003.

BERRINI, Beatriz. Mulher, mulheres. In: __. Ler Saramago: o romance. Lisboa: Editorial Caminho, 1998. pp. 139-182.

CERDEIRA, Teresa Cristina. José Saramago entre a história e a ficção: uma saga de portugueses. Lisboa: Dom Quixote, 1989.

Mulheres e revolução: a cultura marialva posta em questão. In:

O avesso do bordado. Ensaios de literatura. Lisboa: Editorial Caminho, 2000, pp. 213-224.

CHAUÍ, Marilena. Janela da alma, espelho do mundo. In: NOVAES, Adauto (org.). O olhar. São Paulo: Companhia das Letras, 1995. pp. 31-63.

CLÉMENT, Catherine; KRISTEVA, Julia. O feminino e o sagrado. Rio de Janeiro: Rocco, 2001.

COSTA, Horácio. Alegorias da desconstrução urbana: The memoirs of a survivor, de Doris Lessing e Ensaio sobre a cegueira, de José Saramago. In: BERRINI, Beatriz (org.). José Saramago: uma homenagem. São Paulo: EDUC, 1999. p. 127-148. 
DELUMEAU, Jean. O pecado e o medo: a culpabilização no Ocidente. Trad. Álvaro Lorencini. Bauru, SP: EDUSC, 2006. 2 v.

FIGUEIREDO, Monica. Ruínas, vestígios e silêncios: Lilias Fraser, de Hélia Correia. In: RIOS, Otávio (org.). O Amazonas deságua no Tejo: ensaios literários. Manaus: UEA Edições, 2009. pp. 149-155.

GARRETT, Almeida. Viagens na minha terra. Organização, fixação de texto, prefácio e notas de Augusto da Costa Dias. Lisboa: Estampa, 1992.

KRAMER, Heinrich \& SPRENGER, James. Malleus Malleficarum: o martelo das feiticeiras. Rio de Janeiro: Record, 2004.

LANCIANI, Giulia \& TAVANI, Guiseppe. Dicionário da Literatura Medieval Galega e Portuguesa. Lisboa: Caminho, 2000.

LIPOVETSKY, Gilles. A terceira mulher: permanência e revolução do feminino. Trad. Maria Lúcia Machado. São Paulo: Companhia das Letras, 2000.

MACEDO, Helder. Três faces de Eva: imagens do feminino na poesia medieval galego-portuguesa. In: Metamorfoses. Lisboa, Editorial Caminho, n. 3, pp. 201-214, 2002.

MARINHO, Maria de Fátima. A lição de Blimunda. Porto: Areal Editores, 2009.

RECTOR, Monica. Mulher - objecto e sujeito da Literatura Portuguesa. Porto: Edições Universidade Fernando Pessoa, 1999.

SANT'ANNA, Afonso Romano de. A cegueira e o saber. Rio de Janeiro: Rocco, 2006.

SARAMAGO, José. Ensaio sobre a cegueira. São Paulo, Companhia das Letras, 1995b.

. Memorial do Convento. Rio de Janeiro: Bertrand Brasil, 1995a.

. Caim. São Paulo: Companhia das Letras, 2009.

SEIXO, Maria Alzira. Lugares da ficção em José Saramago. Lisboa: Imprensa Nacional Casa da Moeda, 1999.

TEIXEIRA, Vanessa Ribeiro. As alegorias dos sentidos e as reconfigurações da história no Memorial do convento e n’A gloriosa família. (Tese de Doutorado). Rio de Janeiro: UFRJ, Faculdade de Letras, 2009.

(Recebido para publicação em 14/10/2011, 


\section{NOTAS}

1 Referimo-nos à cantiga de Pêro Meogo, "Levou-s’a louçana,/levou-s’a velida;/vai lavar cabelos/na fontana fria./Leda dos amores,/dos amores leda” (Lanciani \& Tavani, 2000, p. 46).

2 De acordo com Bataille (1987), o erotismo também se exerce na relação do homem com Deus: o "erotismo sagrado".

3 Os nomes das personagens serão mantidos em letras minúsculas a fim de que possamos diferenciá-los das personagens bíblicas.

4 Há mais uma versão, neste caso, do Novo Testamento: O Evangelho segundo Jesus Cristo (1991), o qual concedeu a Saramago o Prêmio Camões de Literatura em 1995.

5 A lembrarmos que nod, em hebraico, significa "exílio"; é, portanto, a terra dos exilados. Por tal motivo, há uma assimetria do tempo de nod em relação ao tempo da humanidade.

6 Seguimos a ordem cronológica do tempo que se passa nas narrativas, desconsiderando a ordem de publicação dos romances.

7 Isto ocorre somente em algumas traduções mais antigas da Bíblia, como a edição de 1819 de João Ferreira de Almeida e outras que antecederam a sua morte.

8 Como Marta Maria, a mãe de Baltasar, cujo ventre semeou tanto a vida quanto a morte. 